\title{
PERTUMBUHAN TFP DAN PENGEMBANGAN EFISIENSI PRODUKSI
}

\author{
Endy Dwi Tjahjono \\ Donni Fajar Anugrah ${ }^{1}$
}

\begin{abstract}
A b s tract
This paper investigates both the accumulation and the quality of the input factors with stochastic frontier production function model. The application of the model also enables us to predict the technical efficiency of the input factors for each province of Indonesia.

The model result shows that the capital and the labor share to output are 0.4 and 0.6 respectively. In all Indonesia regions, the quality of the labor or human capital affects the output, but the effect is so small, especially in East Indonesia. Meanwhile, the quality of capital is decreasing by the time and has a negative small coefficient for all regions.

The technical efficiency of all Indonesia regions has increased during the observation period. In the region side, the technical efficiency of the provinces in Sumatra has increased by the time, yet provinces in the other regions tend to decrease. Meanwhile, the technological progresses with no different among regions have a decreasing TFP trend.
\end{abstract}

Keywords: Production, Capital and TFP, Model Stochastic Frontier with Panel Data JEL Classification: C33, D24

1 Peneliti Ekonomi di Biro Riset Ekonomi (BRE), Direktorat Riset Ekonomi dan Kebijakan Moneter (DKM), Bank Indonesia. Pandangan dalam paper ini semata-mata merupakan pandangan penulis dan tidak merefleksikan pandangan DKM atau Bank Indonesia. Kesalahan atau kekeliruan yang ada adalah semata-mata kesalahan penulis. E-mail: endydt@bi.go.id dan donni@bi.go.id 


\section{PENDAHULUAN}

\section{I.1. Latar Belakang}

Studi terdahulu² telah menyimpulkan bahwa pertumbuhan ekonomi Indonesia dalam jangka panjang, terutama selama kurun waktu 2 dekade terakhir (1985-2005), ternyata lebih banyak disumbangkan oleh faktor tenaga kerja (labor) dibandingkan faktor lainnya yaitu capital dan kemajuan teknologi (technological progress). Sejalan dengan berkembangnya endogenous growth theory yang mencoba melihat lebih dalam faktor-faktor lain diluar faktor input dan exogenous TFP, beberapa pertanyaan masih mengemuka dalam rangka memahami sumbersumber pertumbuhan ekonomi Indonesia selama ini.

Pertanyaan pertama adalah apakah hanya kuantitas faktor input saja yang mempengaruhi output? Bagaimana dengan kualitas dari faktor input tersebut? Indikator apa yang bisa digunakan untuk mengukur kualitas atau tingkat produktivitas dari faktor input?

Pertanyaan kedua, apakah hanya kedua faktor produksi itu saja yang menjadi sumber pertumbuhan selama ini. Hal ini mengingat beberapa literatur menyimpulkan bahwa disamping kuantitas faktor input, efisiensi didalam penggunaan faktor input juga berpengaruh meningkatkan laju pertumbuhan ekonomi. Bagaimana cara mengukur tingkat efisiensi dalam penggunaan faktor input?

Pertanyaan ketiga, terkait dengan asumsi yang digunakan dalam Solow Model, dimana tingkat penguasaan teknologi hampir merata di semua negara dirasakan kurang realistis. Dalam lingkup Indonesia kiranya menarik untuk meneliti apakah ada perbedaan yang signifikan pada tingkat penguasaan teknologi antara propinsi-propinsi di Jawa, Sumatera, dan Indonesia Timur (IDT) mengingat adanya kesenjangan yang masih lebar, terutama dalam hal tingkat pendidikan tenaga kerja, jumlah dan kualitas universitas/sekolah, serta infrastruktur yang tersedia. Oleh karena itu, perlu penelitian yang mendalam untuk mengukur seberapa jauh kemajuan tingkat penguasaan teknologi antar wilayah di Indonesia.

Didalam mengukur tingkat penguasaan teknologi dan efisiensi, perlu dilihat juga pergerakannya antar waktu (time varying) apakah menunjukkan trend yang meningkat atau menurun. Propinsi mana saja yang menunjukkan perkembangan terbaik selama ini. Berbagai informasi ini sangat penting dalam menetapkan alokasi anggaran Pemerintah serta menjadi masukan bagi Pemda dalam meningkatkan pembangunan di daerahnya.

2 Tjahjono, Endy D., dan Anugrah, Donni F.," Faktor-Faktor Determinan Pertumbuhan Ekonomi Indonesia", LHP/10/2006, Kelompok Riset Ekonomi, Biro Riset Ekonomi, DKM, Bank Indonesia, Juni 2006 


\section{I.2. Tujuan Penelitian}

- Menganalisis kuantitas dan kualitas faktor input yang mendorong pertumbuhan ekonomi baik secara nasional maupun regional.

- Membuktikan apakah semua propinsi menggunakan level teknologi yang sama, atau apakah terdapat perbedaan antara wilayah Jawa dan luar Jawa.

- Bila terdapat perbedaan, perlu dibuktikan juga apakah di tiap kelompok juga menunjukan adanya perbedaan tingkat efisiensi dalam menggunakan faktor input.

- Melihat peningkatan efisiensi dan produktivitas di propinsi-propinsi pada wilayah mana yang menunjukan peningkatan efisiensi seiring bertambahnya waktu (time varying)

\section{I.3. Ruang Lingkup Penelitian}

Penelitian dibatasi pada periode 1985-2005 dengan frekuensi data tahunan, karena keterbatasan ketersediaan data. Penelitian mencakup 26 propinsi, dimana data 7 propinsi baru digabungkan dalam data propinsi asalnya dan data propinsi Timor-Timur dikeluarkan dalam perhitungan, karena sudah bukan termasuk bagian dari Indonesia.

Penelitian difokuskan pada analisis kuantitas dan kualitas faktor input yaitu stok kapital dan tenaga kerja, serta tingkat efisiensi faktor-faktor tersebut. Selain itu, juga dilakukan analisis pada kemajuan teknologi dan perkembangan TFP. Analisis empirik dilakukan secara nasional dan regional dengan membagi Indonesia menjadi tiga wilayah yaitu Sumatera, Jawa dan Indonesia Timur yang meliputi Kalimantan, Sulawesi, Maluku dan Papua.

\section{TINJAUAN LITERATUR}

Penelitian mengenai sumber-sumber yang mempengaruhi pertumbuhan ekonomi (growth) dengan menggunakan growth theory terus berkembang. Dimulai dengan exogenous growth theory yang memperlakukan penguasaan teknologi sebagai exogenous factor, hingga berkembang menjadi endogenous growth theory dengan menjadikan perkembangan teknologi sebagai endogenous factor. Namun demikian, masih terdapat beberapa kekurangan dalam model-model yang berdasarkan growth theory tersebut seperti model Solow Swan dan model Mankiw-Romer-Weill (MRW). Kekurangan model-model tersebut antara lain belum menjelaskan produktivitas dan efisiensi faktor input-nya. Untuk mengatasinya, telah berkembang model stochastic frontier production function yang mencoba menjelaskan kedua hal tersebut. 


\section{II.1. Growth Theory}

Sebagai dasar dari teori neo klasik economic growth adalah neoclassical production function dengan asumsi bahwa semua input untuk produksi dapat dikelompokkan secara keseluruhan dalam tiga faktor yaitu stok kapital, tenaga kerja, dan teknologi. Fungsi produksi menjelaskan bagaimana perekonomian mengkombinasikan ketiga faktor input tersebut untuk menghasilkan output yang diukur melalui Produk Domestik Bruto (PDB).

Untuk memudahkan penjelasan, kita ibaratkan PDB sebagai satu barang misalnya rokok, dimana untuk memproduksi rokok tersebut diperlukan tiga faktor input sebagai berikut:

1. Capital

Dalam pembuatan rokok, diperlukan tembakau, kertas rokok, dan alat memproduksi kotak rokok, dimana input tersebut kita sebut dengan kapital. Kapital ${ }^{3}$ terdiri dari semua input secara fisik misalnya mesin, jalan, computer dan bangunan, dimana barang-barang tersebut memiliki ciri yang umum yaitu barang bersifat fisik yang diperlukan dalam memproduksi suatu barang. Barang tersebut tidak dikonsumsi dan tetap dapat digunakan untuk produksi berikutnya. Pembelian dari barang-barang tersebut disebut sebagai investasi. Selanjutnya, kapital terdiri dari barang yang dibeli perusahaan sebagai faktor input dama proses produksi ke depannya (Sala-i-Martin, 1995).

2. Labor

Untuk memproduksi rokok diperlukan juga pekerja pembuat rokok. Pekerja pembuat rokok tersebut mengolah barang fisik atau kapital untuk menghasilkan rokok. Kita menyebut faktor input kedua sebagai tenaga kerja. Kita mengukur labor sebagai bentuk peran human atau manusia dalam perekonomian, dimana orang bekerja dalam beberapa jam sehari dan sekian hari dalam sebulan, dan 12 bulan dalam setahun. Beberapa orang dalam perekonomian tidak termasuk yang bekerja dalam memproduksi PDB, kemungkinan karena mereka sudah terlalu tua (sudah pensiun) atau terlalu muda (masih kanak-kanak atau remaja), atau karena mereka tidak meperoleh pekerjaan (pengangguran), atau karena mereka memang tidak ingin bekerja untuk memproduksi PDB. Dalam banyak negara, sebagai contoh, wanita sering bekerja dalam proses produksi yang tidak secara langsung dihitung dalam PDB, seperti pekerjaan mengasuh anak.

Banyak peneliti ekonomi menghitung labor dengan menjumlahkan tenaga kerja atau menjumlahkan waktu kerja dalam perekonomian pada suatu periode. Hal ini secara implisit

3 Capital secara fisik diasumsikan tidak termasuk sumber daya keuangan 
mengasumsikan bahwa semua pekerja dan semua waktu kerja memiliki produkvifitas yang sama. Namun, pada kenyataannya kita menemukan bahwa beberapa pekerja ternyata bekerja lebih produktif dibandingkan pekerja lainnya. Produktivitas pekerja dapat ditingkatkan dengan berinvestasi dalam bentuk peningkatan keahlian pekerja untuk meningkatkan skill. Investasi untuk pekerja tersebut lebih dikenal dengan istilah human capital daripada labor atau work. Investasi ini biasanya dalam bentuk health care atau pendidikan (meskipun pada kenyataannya semakin tinggi pendidikan pekerja tidak harus diikuti oleh peningkatan produktivitas). Pendidikan secara umum diperoleh pada sekolah dan tentu saja dapat juga diperoleh melalui on the job training (OJT) atau pengalaman kerja.

Oleh karena itu, Mankiw, Romer, dan Weil (1992) menambahkan faktor input yaitu human capitalyang semula melekat pada faktor labor. Hal ini untuk menjelaskan bahwa pekerja memiliki tingkat produktivitas yang berbeda tergantung pada tingkat keahlian atau pendidikan yang dimiliki oleh pekerja tersebut. Barro (1999) mengajukan cara menghitung human capital dengan menggunakan schooling years yaitu methode perhitungan masa pendidikan formal yang ditempuh oleh pekerja sehingga memiliki suatu keahlian tertentu.

3. Teknologi atau pengetahuan.

Faktor ketiga dalam proses produksi pembuatan rokok adalah formula cara membuat rokok. Sebelum pekerja pembuat rokok sebagai labormengolah faktor input secara fisik (capital) menjadi rokok sebagai output-nya, mereka memerlukan formula bagaimana cara mengolah bahan baku (tembakau) menjadi rokok. Formula atau blue print tersebut disebut sebagai teknologi atau pengetahuan. Kita mengetahui bahwa banyak formula atau methode cara bagaimana membuat rokok, dimana formula yang satu mungkin lebih baik daripada yang lainnya. Pengembangan dalam formula tersebut kita sebut sebagai technological progress (kemajuan teknologi).

Dari keempat faktor produksi tersebut yaitu physical capital, human capital, labor force dan technology digunakan dalam proses produksi untuk menghasilkan output. Namun demikian, model-model tersebut masih belum mampu menjelaskan perbedaan pertumbuhan negaranegara di dunia, terutama negara berkembang. Selain itu, produktivitas dan efisiensi faktor input belum dijelaskan. Hal ini mengingat beberapa literatur menyimpulkan bahwa disamping kuantitas faktor input, tingkat efisiensi didalam penggunaan faktor input juga berpengaruh dalam meningkatkan laju pertumbuhan ekonomi (Gambar III.1).

Selanjutnya akan dibahas mengenai model stochastic frontieryang berusaha menjelaskan tingkat efisiensi dari faktor input. Model stochastic frontrier tersebut akan dijabarkan dengan time varying inefficiency baik dengan balanced panel data maupun dengan unbalanced panel data. Serta juga akan dijabarkan secara matematika proses dalam model stochastic frontier. 


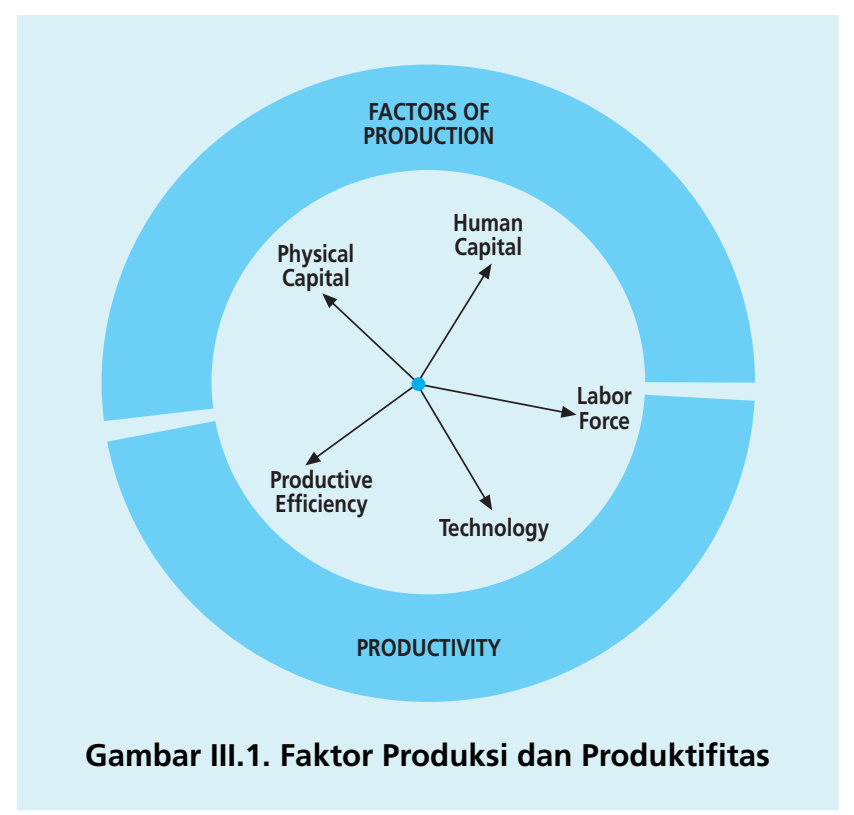

Pengembangan model stochastic frontier dilakukan oleh Limam dan Miller (2003) dengan memasukan variabel pengukur tingkat produktivitas faktor inputyaitu capital dan labor, dimana pengembangan model tersebut digunakan dalam penelitian ini.

\section{II.2. Model Stochastic Frontier}

Untuk menjelaskan efisiensi faktor input, telah dikembangkan model stochastic frontier [Lihat Aigner, Lovell dan Schmidt (1977), Meeusen dan Van den Broeck (1977), Cornwell, Schmidt dan Sickles (1990), dan Kumbhakar (1990)]. Menurut pendekatan ini, yang dimaksud stochastic frontier adalah suatu frontier yang menggambarkan maximum output yang bisa dihasilkan dari faktor input. Actual output akan tepat berada pada frontier bila faktor input digunakan secara efisien. Bila tidak, maka actual output akan berada didalam frontier. Semakin besar gap/ selisih antara frontier dengan aktualnya berarti semakin tidak efisien didalam penggunaan faktor input.

Didalam perjalanannya, gap ini bisa menyempit atau melebar. Perubahan ini bisa disebabkan oleh peningkatan efisiensi didalam penggunaan faktor input atau bisa juga disebabkan oleh pergeseran frontier yang disebabkan oleh kemajuan penggunaan teknologi. Dengan demikian, ada 3 faktor yang berpengaruh terhadap output yaitu perubahan efisiensi penggunaan faktor input, perubahan kemajuan teknologi, dan perubahan faktor input. 


\section{II.2.1. Model Frontier dengan Time-Varying Inefficiency}

Aigner, Lovell dan Schmidt (1977) mengembangkan model stochastic frontier production function yang secara signifikan memberikan kontribusi pada model ekonometrik untuk produksi dan etimasi untuk technical efficiency perusahaan. Stochastic frontier memasukan dua komponen random, dimana salah satunya sebagai technical inefficiency dan yang lainnya sebagai random error. Selanjutnya Schmidt dan Sickles (1984) mengembangkan model stochastic frontier production function dengan panel data sebagai berikut:

$$
y_{i t}=\alpha+X_{i t}^{\prime} \beta+v_{i t}-u_{i t}
$$

dimana:

$y_{i t} \quad=$ output

$X \quad=$ input

$v \quad=$ stastistical noise

$u>0$ adalah firm effect yang mewakili technical inefficiency

Model tersebut dapat dituliskan kembali sebagai berikut:

$$
y_{i t}=\alpha_{i}+X_{i t}^{\prime} \beta+v_{i t}
$$

dimana, $\alpha_{i}=\alpha-u_{i t}$.

Persamaan (III.2) merupakan bentuk baku pada literature panel data, dan $\beta$ dapat diestimasi dengan methode standard, seperti GLS atau Hausman dan Taylor instrumental variables estimator. Selain itu, juga dapat diestimasi menggunakan MLE (Maximum Likelihood Estimator) dengan asumsi particular distribution untuk one side error $u_{i t}$ dalam persamaan (III.1). Schmidt dan Sickles menggunakan model tersebut pada perusahaan penerbangan sebagai panel dengan periode 1970-1977 (periode sebelum deregulasi) dengan asumsi teknologi Cobb Douglas. Hasilnya dengan menggunakan methode GLS dan MLE (asumsi half normal distribution untuk firm effects) sebagai perbandingan, serta spesifikasi error Hausman-Wu ditarik ke dalam pengujian dengan null hypothesis bahwa firm-specific effects tidak berkolerasi dengan regressor-nya.

Keuntungan dari penggunaan panel data yaitu kita dapat memilih apakah menggunakan asumsi particular distribution untuk $v$ dan $u$ atau menggunakan asumsi bahwa technical inefficiency tidak berkorelasi dengan input, oleh karena itu asumsi ini dapat diuji. Meskipun demikian, keuntungannya terutama berasal dari cost menggunakan asumsi bahwa firm effects adalah konstan sepanjang waktu. Hal ini merupakan asumsi yang kuat Namun memiliki peluang menjadi tidak realistis dalam beberapa aplikasi. Dalam kasus aplikasi Schmidt dan Sickles yang 
diterapkan dalam industri penerbangan yang memasuki transisi deregulasi dan setelahnya, potensi untuk productivity pattern (ditunjukan dalam firm effects) tidak stabil seharusnya dapat diatasi. Perusahaan-perusahaan dalam industri penerbangan diperkirakan akan memberikan respon yang berbeda terhadap regulasi yang baru. Isu tersebut telah dibahas oleh Sickles, Johnson (1986), model yang disebutkan di sana merupakan highly parameterized dan membutuhkan maximum likelihood pada higly nonlinear model. Model tersebut merupakan parsimoniously parameterized dan dapat diestimasi secara langsung.

Dalam rangka melepas asumsi bahwa firm effects merupakan time-invariant, namun keunggulan dari panel data tetap diperoleh, kita akan mengganti firm effect dalam persamaan (III.2) dengan parameterisasi fungsi waktu yang fleksible serta parameter yang bervariasi antar perusahaan. Bentuk fungsi yang digunakan yaitu fungsi kuadratik sebagai berikut:

$$
\alpha_{i}=\theta_{i 1}+\theta_{i 2} t+\theta_{i 3} t^{2}
$$

dimana persamaan (III.3) merupakan linear dalam elemen $\theta_{i j}(\mathrm{j}=1,2,3)$.

Bila model yang kita susun dalam bentuk persamaan berikut:

$$
\begin{aligned}
& y_{i t}=X_{i t}^{\prime} \beta+Z_{i}^{\prime} \gamma+W_{i t}^{\prime} \delta_{0}+v_{i t} \\
& v_{i t}=W_{i t}^{\prime} u_{i}+\varepsilon_{i t} \\
& i=1,2, \ldots, N \quad t=1,2, \ldots, T
\end{aligned}
$$

dimana $\delta_{i}=\delta_{0}+u_{i t}, W$ memiliki koefisien tergantung pada $i$, jika $W$ konstan, maka akan berbentuk model panel data dengan intercept bervariasi antar invidvidual atau perusahaan (firm), maka kita memasukan persamaan (III.3) ke dalam bentuk $W$ pada persamaan (III.4), dan kita akan memiliki $W_{i t}^{\prime}=\left[1, t, t^{2}\right]$ dan $\delta_{i}^{\prime}=\left[\theta_{i 1}, \theta_{i 2}, \theta_{i 3}\right]$ dengan menggunakan persamaan (III.2) dapat dituliskan sebagai berikut:

$$
y_{i t}=X_{i t}^{\prime} \beta+W_{i t}^{\prime} \delta_{i}+v_{i t}
$$

Secara jelas spesifikasi pada persamaan (III.3) bermakna bahwa output leve/ bervariasi baik antar perusahaan maupun antar waktu. Sebaliknya, pengukuran produktivitas growth difokuskan pada variasi yang bersifat temporal dan model dapat memberikan rate dari produktivitas growth menjadi bervariasi antar perusahaan.

Time-varying firm productivity dan level efisiensi dan rate dari produktivitas growth dapat diturunkan dari residual berdasarkan within, GLS, dan efficient instrumental variables estimators. Menurut Schmidt dan Sickles (1984) menggunakan model persamaan (III.1), residual $\left(y_{i t}-X_{i t}^{\prime} \hat{\beta}\right)$ merupakan estimasi dari $\left(v_{i t}-u_{i t}\right)$ dan firm effect diestimasi dengan cara merata-ratakan residualnya antar waktu. Secara spesifik, estimasi dari $\alpha_{i}$ sebagai berikut: 
$\hat{\alpha}_{i}=\bar{y}_{i}-\bar{x}_{i} \hat{\beta}$

Estimasi tersebut konsisten dengan $T \rightarrow \infty$

Prosedur untuk model ini yaitu dengan melakukan estimasi $\delta_{i}$ dengan melakukan regresi residual $\left(y_{i t}-X_{i t}^{\prime} \hat{\beta}\right.$ ) untuk perusahaan $i$ pada $W_{i t}$ dengan konstan, waktu dan kuadrat waktu. Nilai fitted dari regresi ini memberikan estimasi dari $\alpha_{i t}$ pada persamaan (III.3) dimana konsisten (untuk semua $i$ dan $t$ ) dengan $T \rightarrow \infty$. Dalam Schmidt dan Sickles, frontier intercept $\alpha$ dan firmspecific level of inefficiency untuk perusahaan ke $i$ diestimasi sebagai berikut:

$$
\hat{\alpha}=\max _{j}\left(\alpha_{j}\right) \text { dan } \hat{u}_{i}=\hat{\alpha}-\hat{\alpha}_{i}
$$

Prosedur di sini dilakukan untuk mengestimasi frontier intercept pada waktu $t$ dan firm specific level dari technical inefficiency untuk perusahaan ke pada waktu $t$ sebagai berikut:

$$
\hat{\alpha}=\max _{j}\left(\alpha_{j t}\right) \operatorname{dan} \hat{u}_{i t}=\hat{\alpha}-\hat{\alpha}_{i t}
$$

\section{II.2.2. Time-Varying untuk Unbalanced Panel Data}

Selanjutnya Battese dan Coelli (1992) mengembangkan model stochastic frontier untuk unbalanced panel data. Pengembangan model stochastic production function dengan simple exponensial specification dari time varying firm effects digabungkan dengan unbalanced panel data, sampel pengamatan $\mathrm{N}$ perusahaan dan periode waktu T. Model didefinisikan sebagai berikut:

$$
Y_{i t}=f\left(x_{i t} ; \beta\right) \exp \left(V_{i t}-U_{i t}\right)
$$

dan

$$
U_{i t}=\eta_{i t} U_{i}=\{\exp [-\eta(t-\mathrm{T})]\} U_{i}, \quad t \in g(i) ; \quad i=1,2, \ldots, N
$$

Keterangan:

$Y_{i t}$ merupakan produksi untuk perusahaan ke $i$ periode ke $t$

$f\left(x_{i t ;} \beta\right)$ fungsi yang tepat untuk vector $x_{i t}$ dari faktor input, dikaitkan dengan produksi perusahaan ke $i$ pada waktu $t$ dan vector $\beta$ berupa unknown parameter.

$V_{i t}$ diasumsikan independen dan distribusi identik $N\left(0, \sigma_{V}^{2}\right)$ random error

$U_{i t}$ diasumsikan independen dan distribusi identik non negative truncation dari $N\left(\mu, \sigma^{2}\right)$ distribution. $\eta$ parameter scalar yang tidak diketahui

$g(i)$ mewakili set $T_{i}$ periode waktu di antara $\mathrm{T}$ periode dengan memasukan persamaan perusahaan ke $t$. 
Model ini seperti non negative firm effect, $U_{i t^{\prime}}$ dimana dapat menurun, jika $\eta>0$ dan tetap jika $\eta=0$ atau meningkat jika $\eta<0$ pada saat t. Bila $\eta$ positif maka perusahaan cenderung meningkatkan level technical efficiency seiring bertambahnya waktu.

Selanjutnya jika periode waktu T merupakan pengamatan untuk perusahaan ke $i$, maka $U_{i T}=U_{i}, i=1,2, \ldots, N$. Sehingga parameter $\mu$ dan $\sigma^{2}$ yang mendefinisikan property statistic firm effects dikaitkan dengan periode terakhir pengamatan dapat diperoleh. Stevenson (1980) mengajukan model dengan asumsi untuk firm effects, $U_{i^{\prime}}$ merupakan generalisasi dari half normal distribution, dimana hal tersebut sering digunakan dalam studi empirik.

Spesifikasi eksponensial pada firm effects over time (persamaan 2) merupakan rigid parameterization dalam technical efficiency (TE) harus meningkat pada decreasing rate $(\eta>0)$, menurun pada increasing rate $(\eta<0)$ atau tetap $(\eta=0)$. Untuk fleksibilitas yang lebih besar dalam nature of technical efficiency, spesifikasi dua parameter dibutuhkan. Spesifikasi dua parameter sebagai alternatif akan diteliti dengan definisi sebagai berikut:

$$
\eta_{i t}=1+\eta_{1}(t-\mathrm{T})+\eta_{2}(t-\mathrm{T})^{2}
$$

dimana $\eta_{1}$ dan $\eta_{2}$ merupakan parameter yang tidak diketahui. Pada model ini, firm effects bisa menjadi convex atau concave, tetapi pada model time invariant merupakan kasus spesial dimana $\left(\eta_{1}=\eta_{2}=0\right)$..

Cornwell, Schmidt dan Sickles (1990) mengasumsikan bahwa firm effects merupakan fungsi kuadratik dari waktu, dimana koefisien bervariasi antar perusahaan disesuaikan dengan spesifikiasi multivariate distribution. Kumbhakar (1990) mengasumsikan bahwa non negatif firm effects, $U_{i t}$, merupakan produk dari fungsi deterministic dari waktu, $\gamma(t)$ dan non negative time invariant firm effect, $U_{i}$. Fungsi waktu $\gamma(t)$ diasumsikan definisinya sebagai berikut:

$$
\gamma(t)=\left[1+\exp \left(b t+c t^{2}\right)\right]^{-1}, \quad t=1,2, \ldots, T
$$

Nilai $\gamma(t)$ antara 0 dan 1 dan dapat monotone decreasing (atau increasing) atau convex (atau concave) tergantung pada nilai parameter $b$ dan $c$. Kumbhakar (1990) menyebutkan bahwa jika $b+c t$ negatif (atau positif), fungsi sederhananya sebagai berikut: $\gamma(t)=\left(1+e^{b t}\right)^{-1}$. Model Kumbhakar (1990) lebih sulit untuk diestimasi dibandingkan model simpler exponential pada persamaan (III.6).

Dari model persamaan (III.5) dan (III.6) dapat terlihat bahwa minimum-mean-squarederror predictor dari technical efficiency perusahaan ke pada waktu periode waktu, sebagai berikut ${ }^{4}$ :

4 dijabarkan secara matematis pada sub bab 2.4 


$$
E\left[\exp \left(-U_{i t}\right) \mid E_{i}\right]=\left\{\frac{1-\Phi\left[\eta_{i t} \sigma_{i}^{*}-\left(\mu_{i}^{*} / \sigma_{i}^{*}\right)\right]}{1-\Phi\left(-\mu_{i}^{*} / \sigma_{i}^{*}\right)}\right\} \exp \left[-\eta_{i t} \mu_{i}^{*}+\frac{1}{2} \eta_{i t}^{2} \sigma_{i}^{* 2}\right]
$$

dimana $E_{i}$ mewakili $\left(T_{i} \times 1\right)$ vector dari $E_{i t}$ dikaitkan dengan periode waktu untuk perusahaan ke $i$, dimana $E_{i t} \equiv V_{i t}-U_{i t}$

$$
\begin{gathered}
\mu_{i}^{*}=\frac{\mu \sigma_{V}^{2}-\eta_{i}^{\prime} e_{i} \sigma^{2}}{\sigma_{V}^{2}+\eta_{i}^{\prime} \eta_{i} \sigma^{2}} \\
\sigma_{i}^{* 2}=\frac{\sigma^{2} \sigma_{V}^{2}}{\sigma_{V}^{2}+\eta_{i}^{\prime} \eta_{i} \sigma^{2}}
\end{gathered}
$$

dimana $\eta_{i}$ mewakili $\left(\mathrm{T}_{i}-1\right)$ vector dari $\eta_{i t}$ dikaitkan dengan periode waktu untuk perusahaan ke $i$, dan $\Phi(\bullet)$ mewakili fungsi distribusi untuk standard normal random variable.

Jika stochastic frontier production function (III.5) merupakan Cobb Douglas atau transcendental logarithmic type, $E_{i t}$ merupakan fungsi linear dari vector $\beta$.

Persamaan (III.7) menghasilkan kasus khusus yang terdapat dalam literatur. Namun demikian, Jondrow, Lovell, Materov dan Schmidt (1982) hanya menurunkan $E\left[U_{i} \mid V_{i}-U_{i}\right]$, hasil yang lebih tepat untuk cross sectional data, $E\left[\exp \left(-U_{i} \mid V_{i}-U_{i}\right]\right.$ diperoleh dari persamaan (III.7) dan (III.9) dengan melakukan substitusi $\eta_{i t}=1=\eta_{i}$ dan $\mu=0$. Untuk kasus dalam Battese dan Coelli (1988) dan Battese, Coelli, dan Colby (1982) diperoleh dari susbtitusi $\eta_{i t} \eta_{i}=T$ dan $\eta_{i}^{\prime} \eta_{i}=T_{i^{\prime}}$ dimana $\eta_{i t}=1$.

Kumbhakar (1990) menurunkan conditional expectation dari $U_{i}$ dengan nilai random variable $E_{i t} \equiv V_{i t}-\gamma(t) U_{i}, \quad t=1,2, \ldots, T$, dengan asumsi $U_{i}$ berupa half normal distribution. Model Kumbhakar (1990) juga menghitung alokasi ineffeciency, tetapi tidak memberikan penerapan secara empiriknya.

Rata-rata technical efficiency dari perusahaan pada periode waktu $t$ sebagai berikut:

$$
T E_{t} \equiv E\left[\exp \left(-U_{i}\right)\right], \text { dimana } \eta_{i}=\exp [-\eta(t-\mathrm{T})]
$$

diperoleh dari straightforward integration dengan density function $U_{i}$ sebagai berikut:

$$
T E_{t}=\left\{\frac{1-\Phi\left[\eta_{t} \sigma-(\mu / \sigma)\right]}{1-\Phi(-\mu / \sigma)}\right\} \exp \left[-\eta_{t} \mu+\frac{1}{2} \eta_{t}^{2} \sigma^{2}\right]
$$

Jika firm effects berupa time invariant, maka rata-rata technical efficiency dari perusahaan di dalam industri diperoleh dari persamaan (III.10) dengan substitusi $\eta_{t}=1$. 


\section{II.3. Pengembangan Model Stochastic Frontier}

Model Stochastic Frontier dikembangkan juga oleh Limam dan Miller (2003) dengan memasukan faktor produktivitas dari faktor input: capital dan labor. Model Limam dan Millar menggunakan asumsi fungsi produksi Cobb Douglas, dimana aggregat output diproduksi dengan menggunakan aggregat stok kapital secara fisik dan labor. Persamaannya sebagai berikut:

$$
Y_{i t}=A_{i} K_{i t}^{\beta_{1 i t}} L_{i t}^{\beta_{2 i t}}
$$

dimana, $Y_{i t}=$ output perusahaan ke $i$ pada waktu $t$

$K_{i t}=$ Kapital perusahaan ke $i$ pada waktu $t$

$L_{i t}=$ Labor perusahaan ke $i$ pada waktu $t$

$A_{t}=A e^{\xi t}$, dimana $\xi$ mengukur rate technical progress

$\beta_{1 i t}=$ elastisitas output terhadap kapital

$\beta_{2 i t}=$ elastisitas output terhadap labor

Untuk melihat pengaruh perbedaan kualitas capitalantar perusahaan, diasumsikan bahwa produktivitas capital tergantung pada rata-rata umur capital. Sementara itu, untuk melihat kualitas labor diasumsikan produktivitas labor tergantung pada level modal SDM. Oleh karena itu, koefisien $\beta_{1 i t}$ dan $\beta_{2 i t}$ merupakan fungsi linear dari usia capital dan pendidikan. Persamaannya sebagai berikut:

$$
\beta_{1 i t}=\alpha_{1}+\alpha_{2} V_{i t}
$$

dan

$$
\beta_{2 i t}=\delta_{1}+\delta_{2} H_{i t}
$$

dimana $V_{i t}=$ rata-rata usia kapital perusahaan ke $i$ pada waktu $t$

$H_{i t}=$ masa pendidikan labor perusahaan ke $i$ pada waktu $t$

Semakin bertambah usia kapital maka akan semakin berkurang produktivitas kapital tersebut sehingga $\alpha_{2}$ tandanya negatif. Sebaliknya semakin tinggi tingkat pendidikan pekerja atau labor maka semakin meningkat produktivitas labor, karenanya $\delta_{2}$ tandanya positif.

Pada tahap berikutnya dengan melakukan substitusi persamaan (III.12) dan persamaan (III.13) ke persamaan (III.11) maka diperoleh persamaan berikut:

$\ln Y_{i t}=\ln A+\alpha_{1} \ln K+\alpha_{2} V \ln K+\delta_{1} \ln L+\delta_{2} H \ln L+\xi t+v_{i t}-u_{i t}$ dimana, $v_{i t}=$ standard two-sided random error $u_{i t}=$ technical inefficiency (Battese dan Coelli, 1992) 
Selanjutnya,

$$
\begin{aligned}
& u_{i t}=\eta_{i t} \cdot u_{i}=\exp [-\eta(t-\mathrm{T})] u_{i} \\
& t=1, \ldots T, \quad i=1, \ldots N
\end{aligned}
$$

dimana

$\eta=$ rate of decline in technical inefficiency

Nilai technical efficiency tiap perusahaan setiap bertambahnya waktu dapat dihitung dengan persamaan:

$$
\left.T E_{i t}=\exp \left[-u_{i t}\right)\right]
$$

\section{MODEL, METHODOLOGY DAN DATA}

\section{III.1 Model}

Model yang digunakan pada penelitian ini pada dasarnya mengikuti model stochastic frontier yang dikembangkan oleh Limam dan Miller (2003) dengan asumsi fungsi produksi Cobb Douglas, dimana aggregat output diproduksi dengan menggunakan aggregat stok kapital secara fisik dan aggregat labor.

Persamaannya sebagai berikut:

$\ln Y_{i t}=\ln A+\alpha_{1} \ln K+\alpha_{2} V \ln K+\delta_{1} \ln L+\delta_{2} H \ln L+\xi t+v_{i t}-u_{i t}$

dimana, $Y_{i t}=$ PDB riil propinsi ke $i$ pada waktu $t$

$K_{i t}=$ Kapital stok propinsi ke $i$ pada waktu $t$

$L_{i t}=$ Kapital stok propinsi ke $i$ pada waktu $t$

$A_{t}=A e^{\xi t}$, dimana $\xi$ mengukur rate technical progress

$V_{i t}=$ rata-rata usia kapital propinsi ke $i$ pada waktu $t$

$H_{i t}=$ masa pendidikan labor propinsi ke $i$ pada waktu $t$

$v_{i t}=$ standard two-sided random error

$u_{i t}=$ technical inefficiency (Battese dan Coelli, 1992)

\section{III.2. Methodologi}

Methodologi yang digunakan dalam penilitian ini menggunakan pendekatan model stochastic frontier. Dalam regresi model digunakan software khusus untuk stochastic frontier production function yang dikembangkan oleh Coelli (1996) yaitu program FRONTIER 4.1. 
Program tersebut menggunakan bahasa program Fortran dengan memasukan penjabaran matematika model stochastic frontier.

Model stochastic frontier yang digunakan akan dikategorikan dalam 4 kelompok model yaitu wilayah Indonesia keseluruhan, wilayah Sumatera, wilayah Jawa, dan terakhir wilayah Indonesia Timur. Masing-masing kelompok (tabel III.1) menggunakan data panel dengan jumlah propinsi sebesar 26 (Indonesia), 8 (Sumatera), 6 (Jawa) dan 12 (Indonesia Timur). Time series data menggunakan periode waktu 1985-2005 mengingat data time series pertumbuhan ekonomi Indonesia dan faktor-faktornya belum memiliki data yang panjang.

\section{III.3. Data}

Data yang digunakan berupa data panel berupa data time series tahunan dalam periode waktu dari tahun 1985 sampai dengan 2005 (21 tahun) dan cross section berupa propinsipropinsi dengan total keseluruhan berjumlah 26 propinsi. Sehingga total data sebesar 546 (21 $x$ 26). Secara aktual, jumlah propinsi di Indonesia saat ini sebesar 33 propinsi, namun terdapat 7 propinsi baru yang dalam perhitungan datanya digabungkan ke dalam propinsi asalnya. Propinsi-propinsi tersebut yaitu Bangka, Banten, Gorontalo, Irian Jaya Barat, Kepulauan Riau, Maluku Utara, dan Sulawesi Barat.

Data regional yang digunakan terdiri dari data PDRB sebagai output riil, stok kapital, usia kapital, tenaga kerja, dan tingkat pendidikan. Stok kapital propinsi diperoleh secara proporsional terhadap stok kapital nasional dengan menggunakan rasio PDRB terhadap PDB. Usia kapital dihitung dengan methode depresiasi dengan asumsi setiap tahun kapital terdepresiasi sebesar $1 / 15$ atau $6.67 \%$. Tingkat pendidikan menggunakan schooling years (Tabel III. 1), dimana tiaptiap tingkat pendidikan disetarakan dengan jumlah tahun yang dibutuhkan untuk menempuh pendidikan tersebut (Barro, 1998).

\begin{tabular}{|c|c|c|c|c|c|}
\hline \multicolumn{6}{|c|}{$\begin{array}{c}\text { Tabel Ill.1 } \\
\text { Schooling Years }\end{array}$} \\
\hline & Lulus SD & Lulus SMP & Lulus SLTA & Lulus D3 & Lulus S1 \\
\hline Jumlah tahun & 6 & 9 & 12 & 15 & 17 \\
\hline
\end{tabular}




\section{UJI EMPIRIS STOCHASTIC FRONTIER}

Pada bab ini akan dijabarkan hasil uji empiris model stochastic frontier production function pada skala nasional dan regional. Untuk regional yang terdiri dari tiga wilayah di Indonesia yaitu Sumatera, Jawa dan Indonesia Timur akan dilakukan analisis tersendiri. Analisis akan diarahkan faktor kuantitas dan produktivitas input, penguasaan teknologi, dan technical efficiency, termasuk perubahan antar waktunya (time varying).

\section{IV.1. Kuantitas dan Produktivitas Faktor Input}

Teori pertumbuhan (Growth Theory) yang dikembangkan paham Neo Classic hanya memperhitungkan kuantitas faktor input yang berpengaruh terhadap output, dalam hal ini jumlah stok kapital dan labor. Sementara itu, kualitas dari faktor input tersebut tidak diperhitungkan. Untuk melihat apakah produktivitas dari faktor input (capital dan labor) juga berpengaruh terhadap output, digunakan model yang dikembangkan oleh Limam dan Miller (2003). Dalam penelitian ini, perbedaan kualitas kapital diukur dari usia kapital dan kualitas diukur dengan schooling years yaitu waktu yang dibutuhkan tenaga kerja dalam menempuh pendidikan formalnya.

Dari hasil running dengan menggunakan software FRONTIER 4.1 dengan panel data 26 propinsi selama 1985-2005 diperoleh hasil pada tabel III.3. Proporsi labor dan stok kapital secara nasional masing-masing sebesar 0.6 dan 0.4. Hal ini sesuai dengan penelitian-penelitian sebelumnya, dimana peran tenaga kerja dalam pertumbuhan ekonomi Indonesia lebih besar dibandingkan peran kapital. Besarnya jumlah angkatan kerja seiring dengan tingginya tingkat populasi di Indonesia yang mencapai 218.868.791 jiwa pada tahun 2005 berperan besar mendorong laju perekonomian.

Proporsi tenaga kerja sebesar 0,6 artinya bahwa peningkatan tenaga kerja sebesar $1 \%$ akan mendorong kenaikan output sebesar $0.6 \%$. Sehingga bila perhitungannya dibalik maka diperoleh bahwa kenaikan output sebesar $1 \%$ dapat dicapai bila labor meningkat sebesar $1.67 \%$ atau dengan kata lain dapat disimpulkan bahwa pertambahan output sebesar $1 \%$ akan menghasilkan peningkatan penyerapan tenaga kerja sebesar $1.67 \%$.

Dari sisi kapital, peningkatan kapital sebesar $1 \%$ akan mendorong peningkatan output sebesar $0.4 \%$. Atau, untuk menambah output sebesar $1 \%$ diperlukan peningkatan kapital sebesar 2.5\%. Sementara itu, Incremental Capital Output Ratio (ICOR) atau perbandingan antara kebutuhan investasi dan pertumbuhan output pada tahun 2005 sebesar 4.2 (Gambar III.2) lebih tinggi dibandingkan hasil running model. Hal ini menunjukan bahwa secara rata- 
rata dari tahun 1985-2005 penambahan kapital sebesar 2.5 unit akan menambah 1 unit output, sedangkan untuk periode 2004-2005 penambahan investasi 4.2 unit akan menambah 1 unit output.

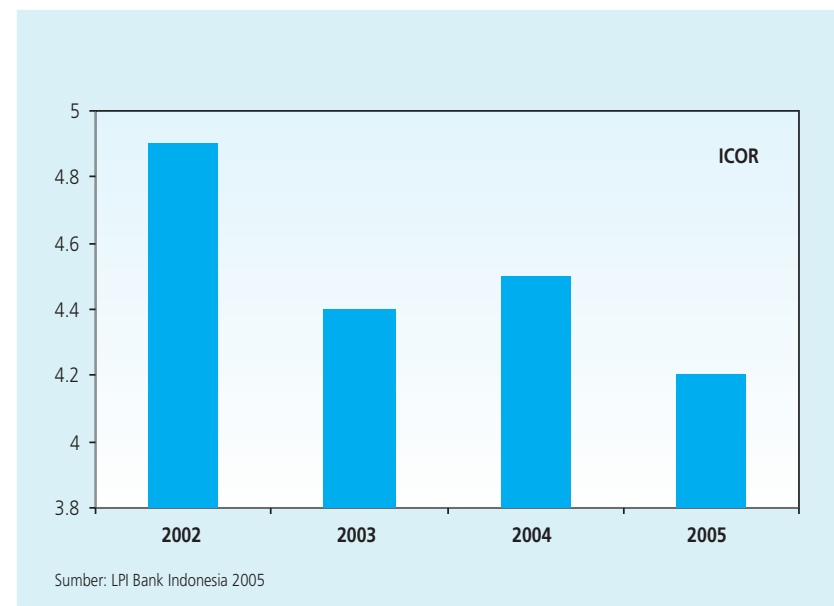

Gambar III.2. Perkembangan ICOR

Ditinjau dari sisi produktivitas, penambahan usia capital di Indonesia berhubungan negatif dengan pertumbuhan ekonomi, namun pengaruhnya cukup kecil. Hasil uji empirik menunjukan koefisien usia kapital sebesar minus 0.009 dan signifikan. Secara teori, tingkat produktivitas capital akan menurun seiring dengan bertambahnya waktu, sehingga memiliki hubungan negatif dengan pertumbuhan ekonomi.

\begin{tabular}{|c|c|c|c|c|}
\hline \multicolumn{5}{|c|}{$\begin{array}{c}\text { Tabel III.2 } \\
\text { Hasil Empirik Stochastic Frontier }\end{array}$} \\
\hline Variabel & $\begin{array}{l}\text { Model } 1 \\
\text { Indonesia }\end{array}$ & $\begin{array}{l}\text { Model } 2 \\
\text { Sumatera }\end{array}$ & $\begin{array}{l}\text { Model } 3 \\
\text { Jawa }\end{array}$ & $\begin{array}{l}\text { Model } 4 \\
\text { Ind Timur }\end{array}$ \\
\hline \multirow[t]{2}{*}{ Intercept } & 5.321 & 5.559 & 5.179 & 5.384 \\
\hline & $(0.057)$ & (0.158) & $(0.299)$ & (0.871) \\
\hline \multirow[t]{2}{*}{ Labor } & 0.604 & 0.589 & 0.615 & 0.596 \\
\hline & $(0.004)$ & (0.011) & $(0.024)$ & (0.062) \\
\hline \multirow[t]{2}{*}{ Kapital } & 0.395 & 0.398 & 0.389 & 0.394 \\
\hline & $(0.002)$ & $(0.003)$ & $(0.007)$ & $(0.004)$ \\
\hline \multirow[t]{2}{*}{ Education } & 0.006 & 0.015 & 0.020 & 0.001 \\
\hline & $(0.001)$ & (0.005) & (0.008) & (0.004) \\
\hline \multirow[t]{2}{*}{ Age } & -0.009 & -0.019 & -0.015 & -0.002 \\
\hline & $(0.001)$ & $(0.002)$ & $(0.003)$ & $(0.007)$ \\
\hline
\end{tabular}




\begin{tabular}{|c|c|c|c|c|}
\hline \multicolumn{5}{|c|}{$\begin{array}{c}\text { Tabel III.2 } \\
\text { Hasil Empirik Stochastic Frontier (lanjutan) }\end{array}$} \\
\hline Variabel & $\begin{array}{c}\text { Model } 1 \\
\text { Indonesia }\end{array}$ & $\begin{array}{l}\text { Model } 2 \\
\text { Sumatera }\end{array}$ & $\begin{array}{l}\text { Model } 3 \\
\text { Jawa }\end{array}$ & $\begin{array}{l}\text { Model } 4 \\
\text { Ind Timur }\end{array}$ \\
\hline $\mathrm{T}$ & $\begin{array}{r}-0.006 \\
(0.0009)\end{array}$ & $\begin{array}{r}-0.012 \\
(0.002)\end{array}$ & $\begin{array}{r}-0.012 \\
(0.006)\end{array}$ & $\begin{array}{l}-0.003 \\
(0.009)\end{array}$ \\
\hline$\sigma^{2}$ & $\begin{array}{r}0.006 \\
(0.0004)\end{array}$ & $\begin{array}{r}0.005 \\
(0.0006)\end{array}$ & $\begin{array}{r}0.005 \\
(0.0007)\end{array}$ & $\begin{array}{r}0.007 \\
(0.0008)\end{array}$ \\
\hline$\gamma$ & $\begin{array}{r}0.0002 \\
(0.0002)\end{array}$ & $\begin{array}{r}0.003 \\
(0.031)\end{array}$ & $\begin{array}{l}0.0008 \\
(0.032)\end{array}$ & $\begin{array}{r}0.00000001 \\
(0.0003)\end{array}$ \\
\hline$\mu$ & $\begin{array}{l}-0.002 \\
(0.022)\end{array}$ & $\begin{array}{r}-0.008 \\
(0.058)\end{array}$ & $\begin{array}{r}-0.004 \\
(0.080)\end{array}$ & $\begin{array}{r}-0.00002 \\
(0.356)\end{array}$ \\
\hline$\eta$ & $\begin{array}{r}0.004 \\
(0.077)\end{array}$ & $\begin{array}{l}0.0002 \\
(0.101)\end{array}$ & $\begin{array}{r}-0.001 \\
(0.273)\end{array}$ & $\begin{array}{l}-0.003 \\
(0.692)\end{array}$ \\
\hline LLF* & 599.833 & 202.034 & 150.555 & 267.971 \\
\hline $\mathrm{N} \times \mathrm{T}$ & 546 & 168 & 126 & 252 \\
\hline
\end{tabular}

Sementara itu, kualitas tenaga kerja yang ditunjukkan oleh tingkat pendidikan tenaga kerja atau modal SDM berperan positif dalam mendorong perekonomian, meskipun pengaruhnya relatif kecil dengan koefisien sebesar 0.006. Masih rendahnya peran modal SDM di Indonesia menunjukan bahwa produktivitas tenaga kerja di Indonesia perlu terus ditingkatkan melalui pengembangan tingkat pendidikan tenaga kerja. Untuk itu peningkatan porsi belanja pendidikan dari total belanja pemerintah harus ditambah untuk meningkatkan mutu pendidikan di Indonesia, baik secara kuantitas maupun kualitas.

\section{IV.2. Pengembangan Technical Efficiency dan Penguasaan Teknologi}

Battese dan Coelli (1992) menyebutkan bahwa bila parameter $\eta$ positif maka technical efficiency akan meningkat seiring dengan bertambahnya waktu, sebaliknya bila parameter $\eta$ negatif maka technical efficiency akan menurun seiring dengan laju waktu. Hasil empiris menunjukan bahwa parameter $\eta$ positif untuk wilayah Indonesia secara keseluruhan. Plot gambar III.2 menunjukan terjadinya perubahan pada tingkat efisiensi faktor produksi di Indonesia dengan kecenderungan meningkat mengikuti perubahan waktu. Hal ini cukup menggembirakan dimana menunjukan pemanfaatan faktor produksi seperti capital dan labor cukup efisien dan cenderung semakin efisien dari tahun 1985 sampai dengan 2005.

Dalam pengelompokan tiga wilayah di Indonesia, hanya wilayah Sumatera yang memiliki trend peningkatan technical efficiency dengan nilai $\eta$ sebesar 0.0002 . Sementara itu, wilayah 
Jawa dan Indonesia Timur meskipun negatif, namun nilai $\eta$ relatif sangat kecil yaitu masingmasing sebesar minus 0.001 dan minus 0.003 . Dari plot trend tingkat efisiensi rata-rata propinsi dalam wilayah tersebut terlihat bahwa wilayah Sumatera memiliki trend meningkat, sedangkan dua wilayah lainnya cenderung menurun (Gambar III.4, III.5 dan III.6).

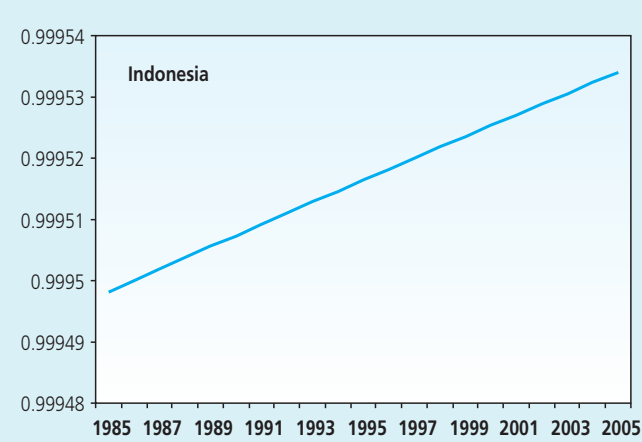

Gambar III.3. TE Indonesia

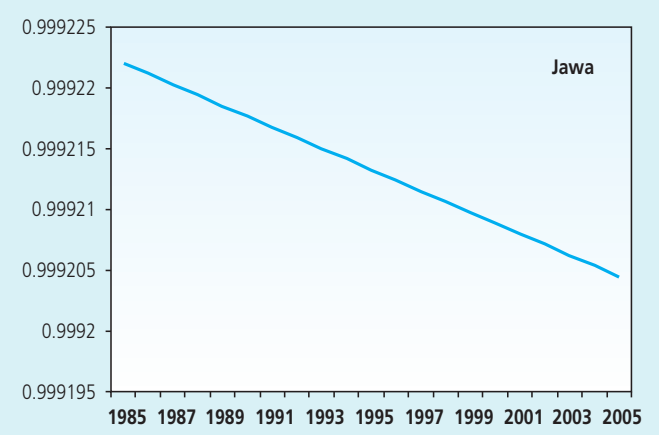

Gambar III.5. TE Jawa

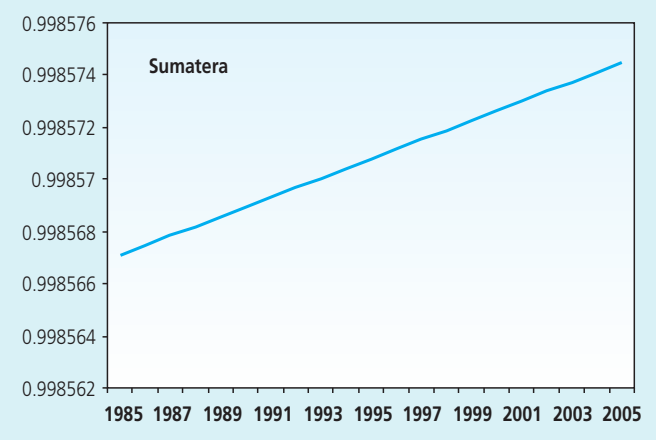

Gambar III.4. TE Sumatera

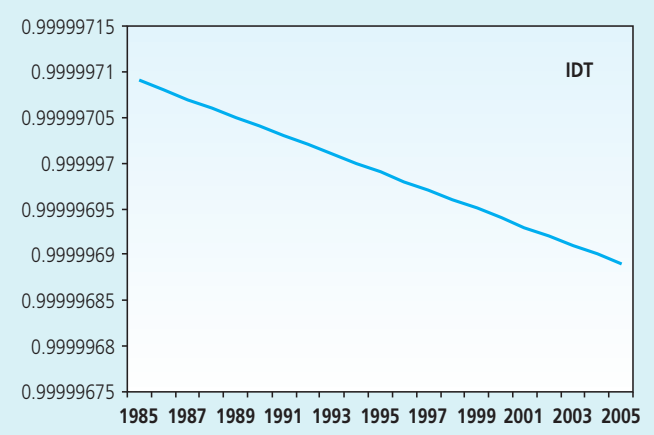

Gambar III.6. TE Indonesia Timur

Dalam penelitian sebelumnya, telah diketahui bahwa TFP baru menyumbang sebesar 0.54\% terhadap pertumbuhan ekonomi Indonesia selama 1985-2005 dari rata-rata pertumbuhan yang mencapai 5.62\%. Kontribusi terbesar masih diperoleh dari tenaga kerja. Yang menjadi pertanyaan berikutnya adalah bagaimana perkembangan TFP dari waktu ke waktu selama periode tersebut dan bagaimana trendnya.

Untuk menjawab pertanyaan tersebut, digunakan pendekatan panel data dengan intercept dan slope yang berbeda mengikuti time trend [Cornwell, Schmidt, dan Sickles (1990) ]. Modelnya 
masih menggunakan persamaan sebelumnya dimana technological progress diasumsikan memiliki bentuk persamaan $A_{t}=A e^{\xi t}$, dimana $\xi$ mengukur rate technical progress sebagai fungsi dari waktu.

Dari hasil estimasi diperoleh hasil bahwa perkembangan TFP ternyata menunjukkan trend yang menurun (koefisien $\xi$ negatif dan signifikan). Penurunan TFP ini bisa mengindikasikan semakin menurunnya tingkat penguasaan teknologi di Indonesia. Dilihat dari wilayahnya, propinsi-propinsi yang berada di Indonesia Timur menunjukkan penurunan yang lebih kecil dibandingkan Pulau Sumatera dan Jawa (Tabel III.1).

Selanjutnya untuk mengetahui apakah tingkat kemajuan teknologi di semua daerah atau propinsi hampir sama, diperlukan pengujian empirik untuk pembuktiannya. Pengujian statistiknya untuk membandingkan apakah terdapat perbedaan yang signifikan antara TFP dari seluruh propinsi dengan cara membandingkan antara sampel secara nasional dan sampel yang dipecah menjadi kelompok Jawa, Sumatera dan Indonesia Timur. Formula $t$ test ${ }^{5}$ yang digunakan sebagai pendekatan kasar untuk pengujian koefisien berikut ini:

$$
t=\frac{\left(\bar{x}_{1}-\bar{x}_{2}\right)-D_{0}}{\sqrt{\frac{s_{1}^{2}}{n_{1}}+\frac{s_{2}^{2}}{n_{2}}}}
$$

Keterangan: $x_{1,2}=$ koefisien teknologi model ke 1 dan 2

$s_{1,2}=$ Standard error koefisien teknologi model ke 1 dan 2

$n_{1,2}=$ jumlah total sampel model ke 1 dan 2

$D_{0}=$ hipotesa perbedaan antara $\mu_{1}$ dan $\mu_{2}$

Hasil pengujian empirik dengan tingkat signifikansi 90\% dengan membandingkan model 1 dengan model 2, 3 dan 4 menunjukan bahwa null hypothsesis dapat diterima, dimana nilai $t$ lebih kecil dibandingkan critical value-nya (Tabel III.3). Sehingga dapat disimpulkan bahwa tidak ada perbedaan kemajuan teknologi antara daerah dan nasional. Hal ini menguatkan hasil empirik pengujian stochastic frontier dimana untuk intercept keempat model memiliki koefisien yang relatif sama yaitu sekitar 5 (Tabel III.2).

5 Anderson, David R., Sweeney, Dennis J., and Williams, Thomas A., Statistics for Business and Economics, South-Western (Thomson), Ohio, 2005. 


\begin{tabular}{|c|c|c|}
\hline \multicolumn{3}{|c|}{$\begin{array}{c}\text { Tabel III.3 } \\
\text { Hasil Pengujian t Test }\end{array}$} \\
\hline Model & Nilai t & Critical Value (10\%) \\
\hline Model 1 dan 2 & 0.868 & 1.285 \\
\hline Model 1 dan 3 & 0.389 & 1.290 \\
\hline & & 1.290 \\
\hline
\end{tabular}

\section{IV.3. Analisis Regional}

Adapun untuk sub kelompok wilayah di Indonesia terbagi dalam tiga wilayah yaitu Sumatera, Jawa, dan Indonesia Timur. Dari sisi kontribusi kapital terhadap pertumbuhan ekonomi, ketiga wilayah memiliki tingkat proporsi yang relatif sama yaitu sekitar $40 \%$. Proporsi kapital terhadap output untuk wilayah Sumatera, Jawa dan Indonesia Timur yaitu masingmasing sebesar 0.4, 0.39, dan 0.39. Hal tersebut menunjukan bahwa peran capital dalam mendorong perekonomian pada ketiga wilayah di Indonesia relatif sama.

Adapun perkembangan stok kapital pada ketiga wilayah yang masing-masing diwakilkan oleh propinsi Riau, DKI Jakarta, dan Kalimantan Timur untuk wilayah Sumatera, Jawa dan Indonesia Timur menunjukan pergerakan yang fluktuatif. Khusus untuk propinsi DKI Jakarta perkembangan stok kapitalnya cenderung meningkat (Gambar III.7).

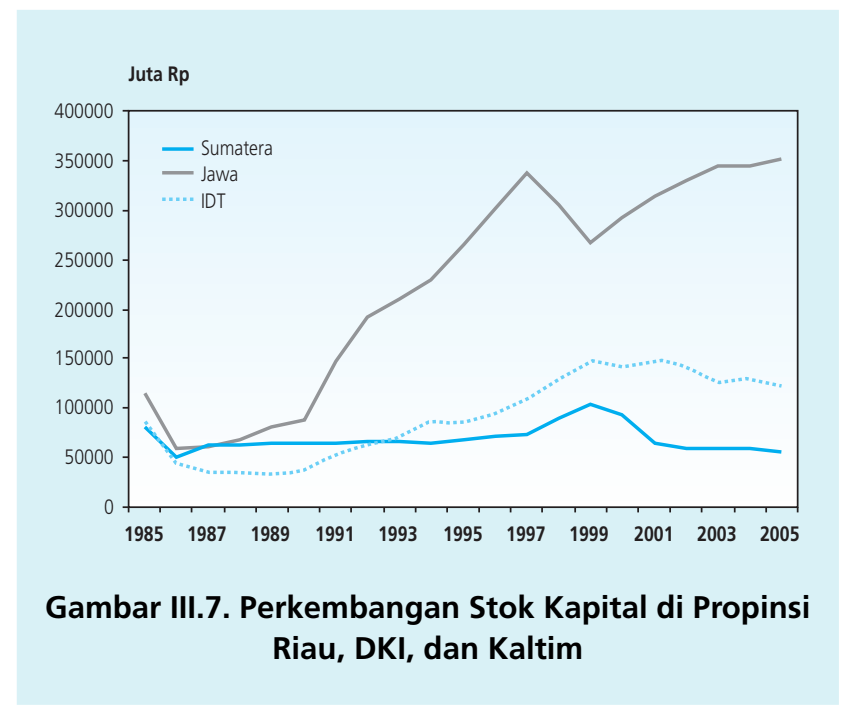

5 Mankiw, N. Gregory, David Romer, and David N. Weil, "A Contribution to the Empirics of Economic Growth", Quarterly Journal of Economics, 1956 
Selain itu, faktor input lainnya yaitu labor juga memiliki pengaruh positif dan signifikan terhadap pertumbuhan ekonomi pada ketiga wilayah, dengan proporsi masing-masing sebesar $0.59,0.61$ dan 0.60 , relatif sama dengan proporsi tenaga kerja secara nasional yang sebesar 0.60. Hal ini menunjukan bahwa peran tenaga kerja dalam mendorong perekonomian daerah hampir sama di seluruh wilayah Indonesia, meskipun jumlah tenaga kerja di masing-masing wilayah berbeda. Perkembangan tenaga kerja pada ketiga wilayah menunjukan peningkatan sepanjang periode 1985-2005. Wilayah Jawa yang diwakili propinsi Jawa Barat memiliki tenaga kerja terbesar diantara ketiga wilayah. Wilayah Sumatera yang diwakili propinsi Sumatera Utara memiliki tenaga kerja yang lebih besar dibandingkan wilayah Indonesia Timur yang diwakili propinsi Kalimantan Selatan (Gambar III.8).

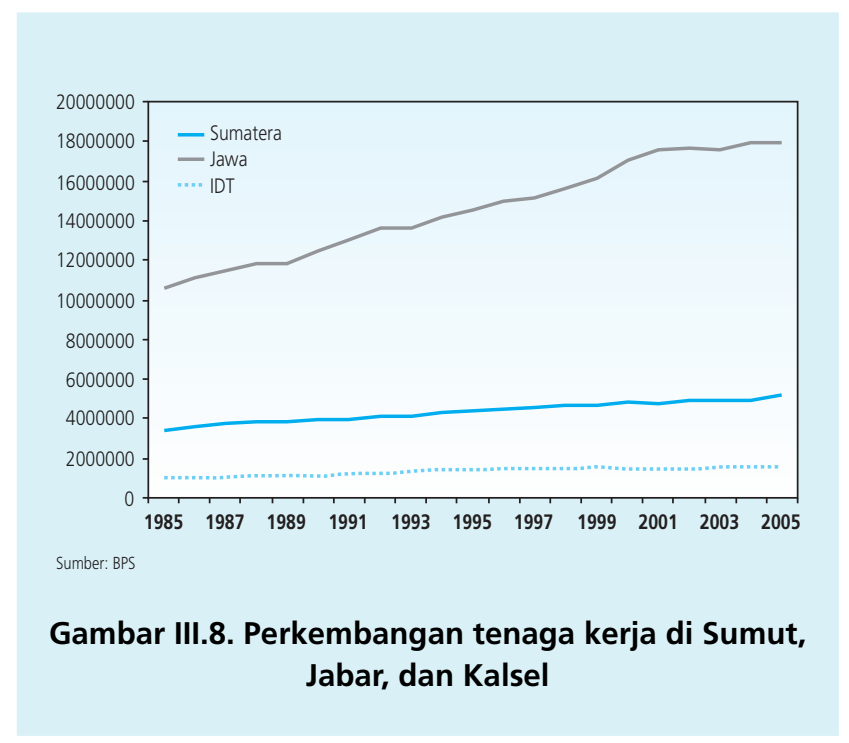

Ditinjau dari sisi kualitas faktor input, faktor pendidikan memberikan kontribusi positif dan signifikan pada pertumbuhan ekonomi di ketiga wilayah. Hal tersebut sesuai dengan teori yang menyebutkan faktor human capital yang memasukan faktor pendidikan pada tenaga kerja berpengaruh positif pada perekonomian ${ }^{6}$. Tingkat produktivitas labor di tiga wilayah memiliki perbedaan, dimana pengaruh modal SDM terhadap pertumbuhan ekonomi wilayah Jawa lebih besar dibandingkan wilayah Sumatera dan Indonesia Timur dengan proporsi sebesar 0.02 (Jawa), 0.015 (Sumatera) dan 0.001 (Indonesia Timur). Rendahnya tingkat pendidikan di wilayah Indonesia Timur dibandingkan wilayah Jawa disebabkan besarnya perbedaan fasilitas

6 Mankiw, N. Gregory, David Romer, and David N. Weil, "A Contribution to the Empirics of Economic Growth", Quarterly Journal of Economics, 1956. 
pendidikan di kedua wilayah tersebut baik secara kuantitas maupun kualitas. Secara kuantitas tercatat jumlah perguruan tinggi swasta di wilayah Indonesia Timur pada tahun 1997 tercatat sebesar 223, masih jauh dibandingkan wilayah Jawa yang tercatat sebesar 807 (Tabel III.4).

Selain itu, terdapat fenomena bahwa penduduk kawasan Indonesia Timur banyak yang melanjutkan studi pada perguruan tinggi di Jawa dan selanjutnya sebagian besar dari mereka tidak kembali ke daerahnya, tapi justru bekerja di Jawa. Hal ini berdampak pada peningkatkan modal SDM di Jawa. Terlihat perkembangan modal SDM di wilayah Indonesia Timur yang sangat rendah dibandingkan wilayah Jawa dan Sumatera (Gambar III.9).

Sebaliknya kualitas capital yang mencerminkan tingkat produktivitas capital tersebut cenderung menurun seiring dengan bertambahnya waktu. Secara teori, penurunan tingkat

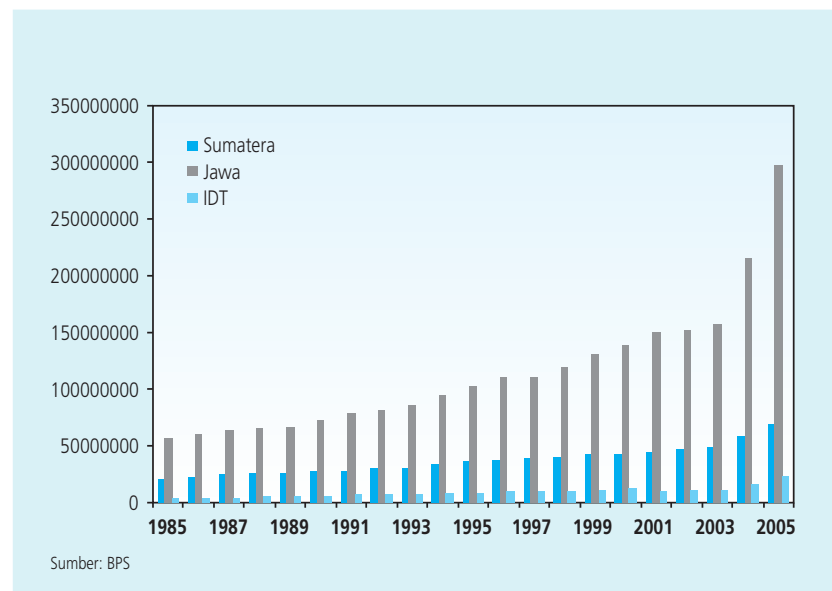

\section{Gambar III.9. Perkembangan Modal SDM Tiga Wilayah di Indonesia}

\begin{tabular}{|c|c|c|c|}
\hline \multicolumn{4}{|c|}{$\begin{array}{c}\text { Tabel III.4 } \\
\text { Jumlah Perguruan Tinggi Swasta }\end{array}$} \\
\hline Jenis & Sumatera & Jawa* & Indonesia Timur \\
\hline Akademi & 78 & 267 & 62 \\
\hline Politeknik & 0 & 9 & 0 \\
\hline Sekolah Tinggi & 132 & 320 & 119 \\
\hline Institut & 4 & 37 & 2 \\
\hline Universitas & 49 & 174 & 40 \\
\hline Jumlah & 263 & 807 & 223 \\
\hline
\end{tabular}


produktivitas capital tersebut karena faktor depresiasi, dimana kualitas capital akan turun terdepresiasi sepanjang waktu. Oleh karena itu tanda koefisien kualitas capital negatif. Hasil pengujian empirik pada ketiga wilayah di Indonesia menunjukan koefisien usia capital negatif dan signifikan (Tabel III.2). Untuk wilayah Sumatera, Jawa dan Indonesia Timur koefisien usia capitalmasing-masing sebesar minus 0.019 , minus 0.015 dan minus 0.002 . Rendahnya koefisien usia capital pada Indonesia Timur dapat disebabkan kurang optimalnya penggunaan capital di wilayah tersebut, sehingga penurunan kualitasnya lebih lambat dibandingkan dua wilayah lainnya.

Sementara itu, kemajuan teknologi atau technological progress (TFP) yang diwakilkan oleh koefisien intercept, dimana untuk wilayah Sumatera, Jawa dan Indonesia Timur masingmasing sebesar 5.56, 5.18, dan 5.38 (tabel III.3). Koefisien ketiga wilayah relatif sama menunjukan bahwa kemajuan teknologi di ketiga wilayah relatif sama. Hal ini juga diperkuat pengujian $t$ test sebelumnya yang menyimpulkan bahwa tidak terdapat perbedaan kemajuan teknologi di Indonesia (Tabel III.3).

Dari sisi trend TFP, tabel III.3 menunjukan bahwa faktor rate technological progress memberikan pengaruh negatif, yang berarti trend TFP cenderung menurun seiring dengan bertambahnya waktu. Hasil uji empirik menunjukan koefisien rate teknologi ketiga wilayah negatif dan signifikan, dengan koefisien wilayah Jawa dan Indonesia Timur sebesar -0.012 dan wilayah Sumatera sebesar -0.014 .

Dilihat dari faktor efisiensi, technical efficiency (TE) faktor input propinsi-propinsi di Sumatera berubah antar waktu (time varying) dengan kecenderungan terus meningkat (Gambar III.10). Sementara itu propinsi-propinsi di wilayah Jawa dan Bali menunjukan tingkat efisiensi faktor input yang berubah antar waktu dengan trend menurun (Gambar III. 11). Adapun propinsi-

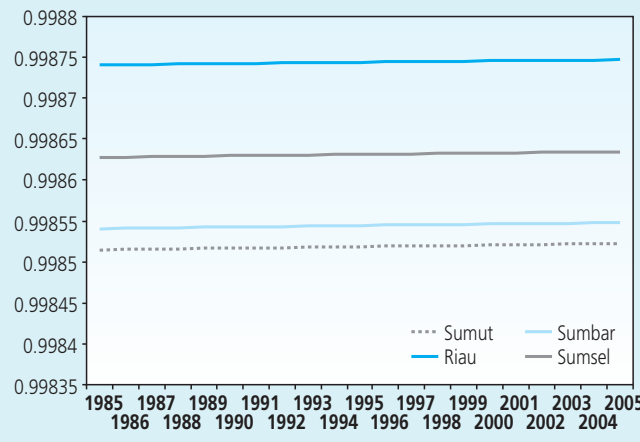

Gambar III.10. TE Propinsi di Sumatera

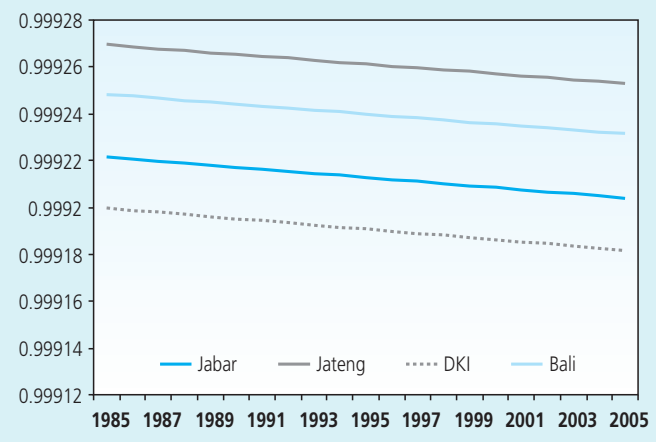

Gambar III.11. TE Propinsi di Jawa dan Bali 
propinsi di wilayah Indonesia Timur memiliki TE yang relatif sama dan berubah antar waktu dengan kecenderungan menurun (Gambar III.6).

\section{KESIMPULAN DAN SARAN}

\section{V.1. Kesimpulan}

Model stochastic frontier production function memberikan penjelasan yang belum terjawab pada Model Solow Swan dengan memberikan tambahan informasi bahwa kualitas dan tingkat efisiensi faktor input juga berperan dalam mempengaruhi output. Dari sisi kualitas, faktor usia capita/ berpengaruh negatif terhadap perekonomian. Sebaliknya, faktor pendidikan labor atau modal SDM memiliki pengaruh positif.

Pengaruh kuantitas faktor input yaitu stok kapital dan tenaga kerja positif terhadap output dengan proporsi masing-masing sebesar 0.6 dan 0.4 baik dalam skala nasional maupun regional. Pengaruh modal SDM cukup kecil yaitu sebesar 0.01, dimana wilayah Sumatera dan Jawa memiliki proporsi yang lebih besar dibandingkan proporsi wilayah Indonesia Timur yang hanya sebesar 0.001 .

Sangat kecilnya sumbangan modal SDM di wilayah Indonesia Timur disebabkan kurangnya sarana pendidikan di sana, baik secara kualitas maupun kuantitas. Hal ini juga didukung fakta bahwa jumlah perguruan tinggi di wilayah Indonesia Timur jauh lebih kecil dibandingkan wilayah lainnya. Selain itu, perguruan tinggi terkemuka lebih banyak berada di wilayah Sumatera dan Jawa.

Peran faktor efisiensi pada perekonomian tak dapat diabaikan, hasil empirik menunjukan bahwa technical efficiency (TE) wilayah Indonesia secara keseluruhan terdapat time varying atau berubah antar waktu. Secara rata-rata propinsi di wilayah Sumatera memiliki TE yang cenderung meningkat seiring dengan bertambahnya waktu. Sebaliknya rata-rata propinsi pada wilayah Jawa dan Indonesia Timur memiliki TE yang cenderung menurun. Dari faktor penguasaan teknologi, pembuktian empirik menunjukan bahwa penguasaan teknologi antar wilayah sama dengan koefisien rata-rata sebesar 5.3 dengan trend TFP yang menurun dengan koefisien ratarata sebesar minus 0.01 .

\section{V.2. Saran}

Kemajuan teknologi dan pendidikan untuk mendorong laju pertumbuhan ekonomi di Indonesia perlu terus ditingkatkan, terutama untuk propinsi-propinsi di wilayah Indonesia Timur. 
Peningkatan kualitas dan kuantitas pendidikan dapat mendorong tingkat produktivitas tenaga kerja. Untuk wilayah Indonesia Timur yang tingkat pendidikannya masih kurang dibandingkan wilayah Jawa dan Sumatera perlu mendapat perhatian. Terpusatnya pendidikan di Jawa dan Sumatera terlihat dari jumlah sekolah dan perguruan tinggi perlu diimbangi dengan pembangunan infrastruktur pendidikan di wilayah Indonesia Timur.

Perlunya peran pemerintah dan Bank Indonesia dalam mendorong investor untuk menanamkan modalnya di Indonesia dengan menciptakan iklim investasi yang sehat. Hal ini dapat diperkuat dengan penerbitan peraturan-peraturan baik untuk kalangan industri maupun perbankan yang menunjang pertumbuhan investasi. Adanya investasi baru akan meningkatkan stok kapital dan dapat menggantikan stok kapital yang usia produktivitasnya telah menurun.

Pemanfaatan faktor capital dan tenaga kerja secara efisien dengan mengurangi pemborosan dalam penggunaannya. Dengan efisiensi yang terus meningkat diharapkan dapat mendorong laju perekonomian, terutama untuk propinsi-propinsi di wilayah Jawa dan Sumatera yang trend TE-nya cenderung menurun. 


\section{DAFTAR PUSTAKA}

Agenor, Pierre-Richard, The Economic of Adjustment and Growth, Second Edition, Harvard University Press, 2004

Aigner, Dennis, Lovell, C.A. Knox, and Schmidt, Peter, "Formulation and Estimation of Stochastic Frontier Production Function Models" ,Journal of Econometrics 6, p.21-37, 1977

Barro, Robert J., "Inequality, Growth, and Investment", NBER Working Paper Series, Cambridge, 1999

Battese, G.E., and Coelli, T.J.,"Prediction of Firm Level Technical Efficiencies With a Generalized Frontier Production Function and Panel Data," Journal of Econometrics 38, pp. 387-399, 1988 Battese, G.E., and Coelli, T.J., "Frontier Production Functions, Technical Efficiency and Panel Data: With Application to Paddy Farmers in India", The Journal of Productivity Analysis, 3, p.153-169, Boston, 1992

Coelli, T.J. (1996),"A Guide to FRONTIER Version 4.1: A Computer program for Stochastic Frontier Production and Cost Function Estimation." CEPA Working Paper 97/07, Center for Efficiency and Productivity Analysis, University of New England, Armidale

Eng, Pierre V.D., "Capital Formation and Economic Growth in Indonesia, 1951-2004", Hitotsubashi University, Tokyo, 2005

Enders, Walter, Applied Econometric Time Series, Wiley, 2004

Greene, William H., Econometric Analysis, Fourth Edition, Prentice Hall International, Inc, 2000, p. 557-589

Kumbhakar, S.C. (1990), "Production Frontiers, Panel Data and Time Varying Technical Inefficiency," Journal of Econometrics 46, pp.201-211

Limam, Yasmina R., Miller, Stephen M.,"Explaining Economic Growth: Factor Accumulation, Total Factor Productivity, and Production Efficiency Improvement", March 2004

Mankiw, N. Gregory, Macroeconomics, Fifth Edition, Worth Publishers, 2003

Mankiw, N. Gregory, David Romer, and David N. Weil, "A Contribution to the Empirics of Economic Growth", Quarterly Journal of Economics, 1992

Romer, David, Advanced Macroeconomic, Second Edition, McGraw-Hill, 2001, p.472.

Sala-i-Martin, Xavier and Barro, Robert J., Economic Growth, Third Edition, The MIT Press, 2001 Solow, Robert M.,"A Contribution to the Theory of Economic Growth", Quarterly Journal of Economics, 1956

Tjahjono, Endy D., dan Anugrah, Donni F.," Faktor-Faktor Determinan Pertumbuhan Ekonomi Indonesia", LHP/10/2006, Kelompok Riset Ekonomi, Biro Riset Ekonomi, DKM, Bank Indonesia, Juni 2006

Weil, David N., Economic Growth, First Edition, Pearson Education, 2005 